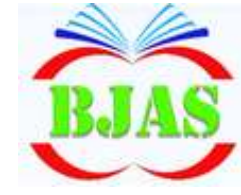

ISSN $1814-5868$
Available online at http://journal.bajas.edu.iq

https://doi.org/10.37077/25200860.2021.34.2.20

College of Agriculture, University of Basrah

\title{
Article Review: Cordia myxa L.: The Gift of the Nature, A Review
}

\author{
Sarah A. Al-Khafaji ${ }^{1}$, Mohenned A. Alsaadawi ${ }^{*}$, Ali M. Al-Yasari ${ }^{3}$ \& Moyed A. \\ Al-Saadawe ${ }^{4}$ \\ ${ }^{1}$ Department of Microbiology, College of Veterinary Medicine, University of Muthanna, \\ Iraq. \\ ${ }^{2}$ Department of Parasitology, College of Veterinary Medicine, University of Muthanna, \\ Iraq. \\ ${ }^{3}$ Department of Physiology, Veterinary Medicine, University of Muthanna, Iraq. \\ ${ }^{4}$ Central South University, China. Working at Alqadissiyah Education Office, Ministry of \\ Education, Iraq \\ *Corresponding author: mohenned.hemza@mu.edu.iq \\ Received $5^{\text {th }}$ April 2021, Accepted $19^{\text {th }}$ September, available; Online $14^{\text {th }}$ December 2021
}

\begin{abstract}
Cordia myxa L. is one of the medical plants that plays an important role in the treatment of many diseases. There are many studies explained that $C$. myxa can show antiinflammatory, anti-diabetic, antiparasitic, antimicrobial and immunomodulatory properties. This review was focused on the active compounds and medical effects of $C$. myxa. The fatty acids contents are particularly high (9.9\%). Sodium and potassium constitute the largest mineral proportion (13 ppm and $29 \mathrm{ppm}$ respectively) of the fruit. However, the toxic heavy metals such as lead, cadmium, chromium and copper have not been found in the fruit. This gives an additional significant benefit of the medical uses of the plant. The content of alkaloids, saponin, polyphenols, and comarine were recorded and was relatively high compared to steroids, resins, glycosides, tannins, and gum that found to be in less amounts. When the mucilage was extracted, the alkaloids constitute more than $35 \%$. By using the Folin-Ciocalteu, C. myxa extracts have a high Phenolic content. The antibacterial activity against gram-negative bacteria were included in the fruit mucilage extract while the alcoholic extracts have no effect on all bacterial isolates. In addition, the mucilage extract showed anti-parasitic activity when it was tested against Leishmania infantum promastigotes. However, the highest concentration of extract significantly reduced the amounts of lymphocytes. Moreover, ethanolic extracts of $C$. myxa fruits give rise to leucocyte and lymphocyte count. Future research needs to be done on this kind of herbs which could show high medicinal activity.
\end{abstract}

Key words: Cordia myxa, nutritional constituents, chemical constituents, antimicrobial activity, antiparasitic, immunomodulatory. 


\section{Introduction}

The medicinal plantspread in different places around the world which are widely used directly and indirectly in many medical applications. Different kinds of drugs were mainly made from these plants, providing the medications with the properties of antiinflammatory, anti-bacterial, anti-fungal, antidiabetic, anti-cancer, anti-oxidant, antihypertensive, anti-mitotic actions and the antibiotic properties with promising vision around lacking of the side effects badly shown by chemical drugs (Anand et al., 2019).

The world's cultures keep in their mind special broad knowledge of how, when and where to use herbal drugs. By looking to the cultural habits relate to the world nation, Plants were used by $75 \%$ of the world's population for care and prevention. (Orhan, 2012). Nearly 72 000 plant types were projected for having medicinal properties of which, India has more than 3000 plant types showing medicinal standards (Saranya et al., 2013). C. myxa fruit, in Iraq known as "Bumber", is one of the major classes of family Boraginaceae that has 300 species have been recognized worldwide in wormer area such as Central and South America, Asia and Africa (Schmelzer \& GuribFakim, 2008). This plant has many medicinal uses as it has very effective ingredients (Aimey et al., 2020). C. mixa distribute around many places with public names as Lasura, Assyrian plim, Pidar, Panugeri, Naruvilli, Geduri, Spistan, Burgund duluwanan or Ntege.

\section{Features of Cordia myxa}

C. myxa is characterized by its broad, alternative, oval shaped. In the flowering season, this kind of herbs carries many white flowers. The diameter of fruits approximately $15-20 \mathrm{~mm}$ and it features a rounded shape set in collections (Fig. 1). Their color yellow is turns blackish after dry. The pulp, has a sweet taste, very hard and mucilaginous (Arbonnier, 2000).

The seeds of $C$. myxa can be considered as an excellent antioxidant agent in our life (Tian et al., 2014). The sweeter contents of C. myxa is considerably high a sweeter fruit due to the high proportion of sucrose, glucose, fructose
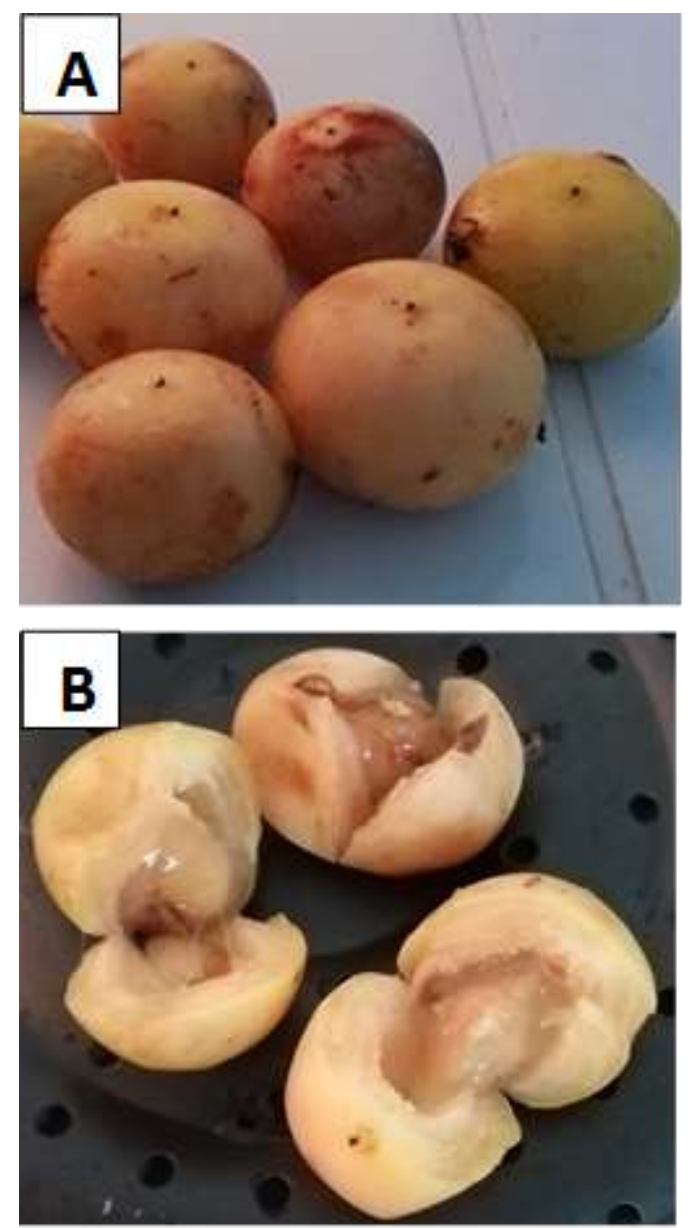

Fig. (1): The fruit of Cordia myxa, (A): The fruit after collecting by the authors from a rural place in AlRumaitha city, in Al-Samawah city, southern of Iraq. (B): Cutting down the fruit; shows the internal appearance and contents of this plant. 
and high total dietary fibers, which in turn can play a major role in limiting the risky effects of several contagious diseases (Aberoumand \& Deokule, 2010). Also, C. myxa fruit consider as a rich source of proteins, fat, carbohydrates, ash, and essential minerals such as $\mathrm{K}, \mathrm{Na}, \mathrm{Ca}$, Fe and Zn (Aljeboury, 2021). This plant has high levels of glycosides, flavonoids, sterols, saponins, terpenoids, alkaloids, phenolic acids, gum and mucilage (Jamkhande et al., 2013). Therefore, the fruit is widely and popularly used for treatment of chest and urinary infections, wound healing (Kuppast \& Nayak, 2006), an anthelminthic, diuretic, astringent, demulcent, expectorant agent, antiinflammatory, and antiarthritic (Abdallah et al., 2011; Al-Musayeib et al., 2011). This review aims to comparison between previous studies in determining the chemical components of the $C$. myxa plant. In addition, it will highlight on the pharmacological effects of $C$. myxa and focus on its antimicrobial activity on the known microorganism.

\section{Geographical distribution}

C. myxa belongs to Boraginaceae family. It is one of the subtropical plants farmed in central and southern Iraq, especially Basrah (Al-Snafi, 2016). The range of its distribution could include the zone extending from the eastern parts of the Mediterranean to eastern Indian parts and was presented in ancient times in tropical Africa, tropical Asia, and Australia. Recently, it was recorded in the Americas (Plants list for C. myxa).

\section{Plant classification (ITIS, 2021)}

Kingdom: Plantae
Subkingdom: Tracheobionta

Superdivision: Spermatophyta

Division: Magnoliophyta

Class: Magnoliopsida

Subclass: Asteridae

Order: Lamiales

Family: Boraginaceae

Genus: Cordia L.

Species: Cordia myxa L.

\section{Morphology of C. myxa}

C. myxa is dioecious plant or small tree equal to $12 \mathrm{~m}$ high; trunk twisting; bark grey, branches distributing, making a thick crown; this plant possesses branchlets hirsute. Its leaves look different, simple; stipules are absent, and the petals length is $0.5-4.5 \mathrm{~cm}$. The edge often ovate, $3-18 \mathrm{~cm} \times 3-20 \mathrm{~cm}$, apex curved to acuminate, borders complete to rough. Inflorescence appear as a slack deadly or little panicle, 3-8.5 cm long, many-flowery; lacking of bracts. Flowers are unisexual, steady, white to creamy; pedicel 1-2 mm long (Jasiem et al., 2016).

Male flowers have campanula cups 4.5-5.5 $\mathrm{mm}$ long, corolla tube is 3-lobed, hirsute inside, and glabrous outside. 3.5-4.5 mm long, 5 oval lobes, c. $5 \mathrm{~mm} \times 2 \mathrm{~mm}$, the stamens introduced at corolla gorge, threads $1.5-3.5 \mathrm{~mm}$ in length. While female flowers contain a campanulate calyx like tubular shape which is $6-8.5 \mathrm{~mm}$ in length, sporadically 3-4-pointy, densely hairy within, glabrous outside, corolla tube $5-7 \mathrm{~mm}$ long, corolla tube $4.5-6.5 \mathrm{~mm}$ in length, contain 4-6 lobes, ovoid in shape, 5-7 mm long, 
the staminodes rolled up with sterilized anthers. Also, the female's ovary is big in size, ellipsoid to ovoid in shape, style $8-9 \mathrm{~mm}$ in length, 4celled with 4 branches $4-5 \mathrm{~mm}$ in length. The fruits of the plant have round to oval drupe 2$3.5 \mathrm{~cm}$ long, at the base surrounded by the crescent yellow, apricot or blackish calyx. Pyrene is approximately ellipsoid to globose, $12 \mathrm{~mm}$ long, intensely wrinkly (Jasiem et al., 2016).

\section{The chemical constituents}

Many previous studies regarding the chemical contents of $C$. myxa fruits showed that fruits are rich in carbohydrate, fat, protein and ash fruit. The highest rate is the carbohydrate and ranging between (57-63\%). The rate of protein was 8.3-8.6\% while the lowest rate was Ash with proportion of $6.7 \%$ (Al-Snafi, 2016; AlHamdani \& Al-Faraji, 2017). However, the percentage of fat was $9.9 \%$ according to (AlHamdani \& Al-Faraji, 2017) while, (Al-Snafi, 2016) found that $2.2 \%$ of the chemical content was fat. The last study was relatively agreed with (Aberoumand, 2011) who mentioned that the concentration of carbohydrates and crude fat were $48.48 \%$ and $2.5 \%$ respectively.

\section{Fatty acids}

The plant composed of high fatty acids contents and concentrations. Al-Hamdani \& Al-Faraji (2017) found that the percentage of fat was 9.9\%. Two kinds of saturated fatty acids; C12 and $\mathrm{C} 14$, were found at proportion of $48.3 \%$ and $15.8 \%$ respectively. While, the rate of oleic acid (unsaturated fatty acid) was $12.4 \%$ (AlHamdani \& Al-Faraji, 2017) which plays a very essential role for health and nutrition of human (Sales-Campos et al., 2013).

\section{Mineral analysis}

According to some mineral analytic research results, the amounts of potassium (29 ppm), and sodium (13 ppm) represent the greatest proportion of minerals found in the fruits (Aberoumand, 2011; Al-Hamdani \& Al-Faraji, 2017). Other minerals distinguished in reasonable quantities were Iron and Magnesium, which were about 0.5 and $0.2 \mathrm{ppm}$ respectively. While, Calcium, Manganese, and copper were $0.07,0.02$ and $0.01 \mathrm{ppm}$ respectively. It is known that minerals can be incorporated in many valuable biological processes. The role of Calcium could be contribution in bone formation and blood coagulation. The main chief of inorganic cation in the extracellular tissue fluids is Sodium (Juel, 1988), while potassium can mainly work as the cation of intracellular cell and also could help in excitability of nerve and muscle (Vaughan, 1991). Iron is vital part of body components as it is a functioning part of haem, an important part of hemoglobin that is essential in respiration (Maughan et al., 2013). The fruits have no lead, cadmium, chromium, and copper thereof, this plant has a very low toxic proportion with heavy metals (Okwu, 2001), While these results did not match the results of the study by Al-Snafi (2016) where the results indicate that sodium $\left(1.62 \mathrm{mg} . \mathrm{g}^{-1}\right)$, potassium $\left(7.83 \mathrm{mg} . \mathrm{g}^{-1}\right)$, calcium $\left(0.46 \mathrm{mg} . \mathrm{g}^{-}\right.$ $\left.{ }^{1}\right)$, zinc $\left(0.35 \mathrm{mg} . \mathrm{g}^{-1}\right)$ and iron $\left(0.51 \mathrm{mg}^{-1} \mathrm{~g}^{-1}\right)$.

\section{Phytochemicals}

The Phytochemical screening of $C$. myxa fruits exhibited the presence of alkaloids, saponin, polyphenols, and comarine with relatively high amounts contents. While, steroid, resins, glycosides, tannins, and gum were less 


\section{Al-Khafaji et al. /Basrah J. Agric. Sci., 34(2), 267-277, 2021}

quantities. These phytochemicals have positively contributed according to their medicinal importance and physiological action. For example, the pharmacology of saponins involves expectorant, antiinflammatory, vasocreptic, hypocholesterolemic, hypoglycaemic, antiparasitic, hypoglycaemic and several others (Sparg et al., 2004). The effects of glycosides are not common; however, their toxic effects could include some adverse impact such as reduction of heart rate, sympathetic activity, and systematic vascular resistance (Ferguson et al., 1989). While Steroidal compounds are very important in pharmacological medications because of their association with sex hormone (Tanner et al., 1976).

The fruits have no lead, cadmium, chromium, and copper thereof, this plant has a very low toxic proportion with heavy metals. The fruit extract has a high concentration of phenolic compounds about $11.1 \pm 1.47 \mathrm{mg} . \mathrm{g}^{-1}$ gallic acid equivalent, which can be obtained by hand macerating the fruit shed. Methanol can be used to extract the solvent phenolic acids of $C$. myxa fruits. The whole phenolic compound was $402 \mathrm{mg} \cdot 100 \mathrm{~g}^{-1}$ (Aberoumand \& Deokule, 2008). C. myxa fruits have phenol contents of approximately $373.91 \pm 13.93$ mg.100 $\mathrm{g}^{-1}$ dry weight, IC50 for antioxidant activity was $132.53 \pm 5.75 \mathrm{mg} \cdot \mathrm{ml}^{-1}$. (Souri et al., 2008). The plant contains eight carotenoids, were determined and recognized. Their percentages were as follows: canthaxanthin $2.4 \%, 19$ '-Z-violaxanthin $6.4 \%$, lutein $18.9 \%$, chlorophyll b\%, violaxanthin $7.3 \%$, allomer $1.7 \%$, chlorophyll-b 22.4\%, chlorophyll-a $29.4 \%$, chlorophyll allomer $1.9 \%, \beta$-carotene $7.0 \%$ and $\alpha \beta$-carotene $1.2 \%$ (Al-Snafi, 2016).
Polyphenols extracted constituent showed antiinflammatory, antibacterial, antiviral, antiallergic, and antineoplastic activity (AlHamdani \& Al-Faraji, 2017).

\section{Nutritional and anti-nutrient properties}

According to several studies $C$. myxa fruits' nutritious and anti-nutrient properties, reported that the fruit of C. myxa has $100 \mathrm{~g}$ of the dried crop: glucose12.75, fructose 9.38, sucrose 29.09 , water 6.21, and starch 29.09. It also had $248.0 \mathrm{mg} .100 \mathrm{~g}^{-1}$ of phytic acid and 1.39 TIU.g${ }^{1}$ of trypsin inhibitor (Al-Snafi, 2016).

\section{The antimicrobial activity}

\section{Extracts of fruits (Mucilage)}

The mucilage extract of $C$. myxa fruit showed antibacterial activity against gram-negative bacteria isolated from urine samples. Different mucilage extract concentrations (1000, 500, 250, 125 and $63.5 \mathrm{mg}$. $\mathrm{ml}^{-1}$ ) exhibit variable inhibition zones $(15,13,13,12$ and $12 \mathrm{~mm})$ respectively in against $E$. coli isolates while at concentration 500, 250 and $125\left(\mathrm{mg} \cdot \mathrm{ml}^{-1}\right)$, the inhibition zones were 10,10 and $8 \mathrm{~mm}$ respectively against Klebsiella pneumonia bacteria. As well as the mucilage extract of $C$. myxa fruit has no effective against either Streptococcus pyogenic or Haemophilus influenza isolates from sputum samples (Jasiem et al., 2016). The inhibition of bacteria increased considerably with increased concentration of fruit extract related to antibiotic inhibition (Al-Hamdani \& Al-Faraji, 2017).

\section{Extracts of leaves (Alkaloids)}


Jasiem et al. (2016) explained that the alcoholic extracts of $C$. myxa leaves can be inactivate against all bacterial isolates. However, (Pandey et al., 2014) found that C. myxa give a good inhibition zone against gram-positive bacteria (S. aureus) and gram-negative bacteria (E. coli) in the high concentration extracts of $C$. myxa leaves that could start with $4.5 \%$. Moreover, they mentioned that the leaf extract of C. myxa cannot be effective on fungi (Pandey et al., 2014). While Ali (2008) did not agree with Jasiem et al. (2016) as he explained that the extracts of C. myxa leaf can show antimicrobial activity against three kinds of bacterial isolates (Escherichia coli, P. aeruginosa and $S$. aureus), and three mycological isolates (Penicillium spp., Aspergillus niger and Scytalidium spp.). While Pandey et al. (2014) found that the alkaloid extract has not antifungal activity.

\section{Antiparasitic and insecticidal effects}

The mucilage extract of C. myxa has an antileishmanial activity. The extract was studied against promastigotes of $L$. infantum (MCAN/IR/96/LON49) and $L$. major (MRHO/IR/75/ER) $\left(1 \times 106\right.$ cells.ml $\left.^{-1}\right)($ Saki et al., 2015). In this study, several concentrations were prepared of the mucilage extract $(0,0.61$, $1.22,2.44,4.88,9.75,19.5,39,78$, and $156 \mathrm{mg}$ $\mathrm{mg} . \mathrm{ml}^{-1} \mathrm{w} / \mathrm{v}$ ) and added to the promastigotes. After that, they were plated in a 96-well microtiter plate, followed by a 72-hour incubation period at $24^{\circ} \mathrm{C}$. The action of antileishmanial was evaluated under the light microscope using a 3-[4,5-dimethylthiazol-2yl]-2,5 diphenyl tetrazolium bromide (MTT) stain. The growth of parasite was checked via using 50\% IC50 value. IC50 of $35 \pm 2.2 \mathrm{mg}$. $\mathrm{ml}^{-1}$ and an IC50 of $26 \pm 2.2 \mathrm{mg} \cdot \mathrm{ml}^{-1}$ of $C$. myxa mucilage extract showed effective lethal dose against promastigotes of $L$. major and $L$. infantum. After 72 hours, the percentage of existence $L$. major and $L$. infantum reached around 16-17\% when $156 \mathrm{mg} \mathrm{mg.} \mathrm{ml}{ }^{-1}$ mucilage extract of C. myxa was used (Saki et al., 2015). Also, C. myxa has antiplasmodial activity as the plant can inhibit parasitic growth and determined through the Plasmodium lactate dehydrogenase production. The antiplasmodial activity of alkaloids extract of $C$. myxa could be high (the IC50 was $6.2 \mu \mathrm{g} \cdot \mathrm{ml}^{-1}$ ), while the antiplasmodial activity of dichloromethane extract which is moderate and the IC50 was $4.2 \mu \mathrm{g} . \mathrm{ml}^{-1}$. However, methanol and aqueous extracts did not have any activity against Plasmodium (Sanon et al., 2013).

\section{Immunomodulatory activity}

The $C$. myxa fruit's aqueous extract was tested on the immune-modulatory activity in mice injected with hydatid cyst fluid antigen HCFAg. Different parameters were studied such as Mitotic index (MI), Delayed type hypersensitivity (DTH), and spleen histopathological changes (Ali, 2008). After 10 days of treatment, the treated mice with aqueous extract of $C$. myxa fruit have increase in the size of the spleen. According to histopathological analysis, the spleen had marked hyperplasia and sometimes developed large follicles. Aqueous extract of C. myxa fruits stimulates cell-mediated immune responses in mice. The ethanolic extract effect of $C$. myxa on immune-modulation of mice was examined in vitro using the lymphoid and phagocytes of the mouse (males' type BALB/c) and tested by NBT stain. The results showed 
that the concentration of lymphocytes was significantly declined compared with negative and positive control. The use of the NBT stain revealed that there is a significant inhibition in the ratio of formazan granules (without cytotoxicity). The ratio of cytotoxicity was increased at higher concentrations of extract, and the number of lymphocytes and phagocytes was significantly reduced $(\mathrm{P}<0.05)$. Moreover, the ethanolic extracts of $C$. myxa fruits rise leucocyte and lymphocyte counts (Ali, 2008).

\section{Antioxidant effect}

Several molecules (enzymes, vitamins, lipids, etc.) can be classified as antioxidants that help suppress free radicals that form in the cells in order to help the organism to produce energy. However, an excessive number of free radicals, such as superoxide, hydroxyl, peroxy, and peroxy radicals are also produced (Valko et al., 2007). A large number of widely accepted and widely acknowledged and well-recognized medical conditions, including cardiovascular disease, obesity, insulinoma, and dementia, have been shown to arise from the production of radicals and their harmful effects on fats and proteins in cells (Maddu, 2019). This innate organism-protecting strategy to protect the cells from the damaging effects of free radicals can only be partly achieved through superoxide dismutase (SOD), glutathione reductase (GR), and the reductase (GSH-RADC) (He et al., 2017). Nowadays, the use of herbal medicines has become increasingly widespread as a treatment for therapeutic issues (Yang et al., 2017). Medicinal plants are of interest because of their pharmacological activities, their economic feasibility, and low toxicity, all of which has resulted in them being the subject of extensive research (Ayoub \& Mehta, 2018). A vast majority of these plants are used for treatment of wounds, cancer, and other inflammatory conditions (Abdel-Aleem et al., 2019). In multicellular organisms, programmed cell death or apoptosis refers to the killing of a cell with a protein released by another cell or organism.

\section{Conclusion}

C. myxa fruits known as "Bumber" is one of the major classes of family Boraginaceae that have been recognized worldwide in wormer area such as Central and South America, Asia and Africa. A large number of earlier studies have shown that the chemical content of C. myxa fruit to be rich in carbohydrate, fat, protein, and ash. The plant contains high amounts of fatty acids $9.9 \%$. The amounts of potassium (29 ppm) and sodium (13 ppm) which represent the largest proportion of minerals found in the fruit, according to some mineral analytical results. Lead, cadmium, chromium and copper have not been found in the fruit, and this is of significant benefit to vital organs because such heavy metals have been identified as toxic. The phytochemical screening of $C$. myxa fruits showed that the presence of relatively high content of alkaloids, saponin, polyphenols, and comarine. While, there were less quantities of steroids, resins, glycosides, tannins, and gum. Mucilage extraction shows that the alkaloid constitutes more than 35 per cent. The FolinCiocalteu reagent was used to determine the Phenolic content of $C$. myxa extracts, which was measured as gallic acid equivalent. $C$. myxa fruit mucilage extract showed antibacterial activity against gram-negative bacteria isolated from urine samples. The 
alcoholic extracts of $C$. myxa leave have no effect on all bacterial isolates. The mucilage extract has anti-leishmanial activity. The extract was tested against $L$. infantum promastigotes. However, the highest concentration of extract significantly reduced the amounts of lymphocytes. Moreover, ethanolic extracts of $C$. myxa fruits give rise to leucocyte and lymphocyte count.

\section{Acknowledgements}

We would like to thank Veterinary Medicine College at Al-Muthanna University for let us use the available sources in the college library.

\section{Orcid}

S. Al_Khafaji: https://orcid.org/0000-0003-0598-0928

M. Alsaadawi : https://orcid.org/0000-0003-1087-015X

A. Al-Yasari: https://orcid.org/0000-0002-6686-4878

M. Al-Saadawe4: https://orcid.org/0000-0001-55945480

\section{References}

Abdallah, I. Z., Khattab, A., \& Heeba, H., (2011). Gastroprotective effect of Cordia myxa L. fruit extract against indomethacin-induced gastric ulceration in rats, Life Science Journal, 8(3), 433445 .

Abdel-Aleem, E. R., Attia, E. Z., Farag, F. F., Samy, M. N., \& Desoukey, S. Y. (2019). Total phenolic and flavonoid contents and antioxidant, antiinflammatory, analgesic, antipyretic and antidiabetic activities of Cordia myxa L. leaves. Clinical Phytoscience, 5, 29. https://doi.org/10.1186/s40816019-0125-z

Aberoumand, A., (2011). Preliminary evaluation of some phytochemical and nutrients constituents of Iranian Cordia myxa fruits, International Journal of Agricultural and Food Science. 1(2), 3033. https://www.semanticscholar.org/paper/PreliminaryEvaluation-of-Some-Phytochemical-and-of-
Aberoumand/c84ddb97518ee231a07e7489efe704d95 fae $68 \mathrm{bb}$

Aberoumand, A., Deokule, S. S., (2008). Comparison of phenolic compounds of some edible plants of Iran and India. Pakistan Journal of Nutrition, 7, 582-585. https://doi.org/10.3923/pjn.2008.582.585

Aberoumand, A., \& Deokule, S. S. (2010). Screening of some nutrients and anti-nutrients components in some plant foods of Iran and India. Journal of Agricultural Technology, 6, 777-781.

Aimey, Z., Goldson-Barnaby, A, \& Bailey, D., (2020). A review of Cordia species found in the Caribbean: Cordia obliqua Willd, Cordia dichotoma G. Forst. and Cordia collococca L. International Journal of Fruit Science, 20, S884-S893. https://doi.org/10.1080/15538362.2020.1772181

Al-Hamdani, M. S., \& Al-Faraji, A. S., (2017). Evaluation of inhibitory activity of Cordia myxa fruit extract on microorganisms that causes spoilage of food and its role in the treatment of certain disease states. Journal of Biology, Agriculture and Healthcare, 7(2), 43-49.

Ali, K. A. (2008). Study of effect of alcoholic extract of fruit of Cordia myxa in total count and differential count of white blood cells in rats. Al-Qadisyia Journal of Veterinary Medicine Sciences, 7(2), 7, 2124. https://qmeds.iraqjournals.com/article_33763.html

Aljeboury, G. H. (2021). Anti-Inflammatory effect of Cordia myxa extract on bacteria that Infected wounds in rats as a model for human. Annals of the Romanian Society for Cell Biology, 25(4), 16040-16045. https://www.annalsofrscb.ro/index.php/journal/article /view/5345

Al-Musayeib, N., Perveen, S., Fatima, I., Nasir, M., \& Hussain, A., (2011). Molecules Antioxidant, Antilycation and Anti-inflammatory activities of phenolic constituents from Cordia sinensis. Molecules, 16, 10214-10226.

https://doi.org/10.3390/molecules161210214

Al-Snafi, A. E., (2016). The Pharmacological and therapeutic importance of Cordia myxa- A review. IOSR Journal of Pharmacy, 6, 4757. 


\section{Al-Khafaji et al. /Basrah J. Agric. Sci., 34(2), 267-277, 2021}

Arbonnier, M., (2000). [Trees, shrubs and lianas of the dry zones of West Africa France]. Montpellier: CIRAD; MNHN. 544pp. (In French) http://publications.cirad.fr/une_notice.php?dk=47638 0

Ayoub, Z., \& Mehta, A. (2018). Medicinal plants as potential source of antioxidant agents: a review. Asian Journal of Pharmaceutical and Clinical Research, 11(6), 50-56. http://dx.doi.org/10.22159/ajpcr.2018.v11i6.24725

Anand, U., Jacobo-Herrera, N., Altemimi, A., \& Lakhssassi, N. (2019). A comprehensive review on medicinal plants as antimicrobial therapeutics: Potential avenues of biocompatible drug discovery. Metabolites, 9(11), 258. https://doi.org/10.3390/metabo9110258

Ferguson, D. W., Berg, W. J., Sanders, J. S., Roach, P. J., Kempf, J. S., \& Kienzle, M. G., (1989). Sympathoinhibitory responses to digitalis glycosides in heart failure patients. Direct evidence from sympathetic neural recordings. Circulation, 80, 6577.

https://www.ahajournals.org/doi/abs/10.1161/01.cir.8 0.1 .65

He, L., He, T., Farrar, S., Ji, L., Liu, T., \& Ma, X. (2017). Antioxidants maintain cellular redox homeostasis by elimination of reactive oxygen species. Cellular Physiology and Biochemistry, 44, 532-553. https://doi.org/10.1159/000485089

ITIS (2021). Integrated Taxonomic Information System - Report. Cordia myxa L., accessed 26 July 2021, https://www.itis.gov/servlet/SingleRpt/SingleRpt?sea rch_topic=TSN\&search_value=565086\#null

Jamkhande, P. G., Barde, S. R., Patwekar, S. L., \& Tidke, P. S., (2013). Plant profile, phytochemistry and pharmacology of Cordia dichotoma (Indian cherry): A review. Asian Pacific Journal of Tropical Biomedicine, 3(12), 1009-1012. https://doi.org/10.1016/S2221-1691(13)60194-X

Jasiem, T. M., Al-Mugdadi, S. F. H., Aljubory, I. S., \& Latef, Q. N., (2016). Phytochemical study and antibacterial activity of crude alkaloids and mucilage of Cordia myxa in Iraq. International Journal of
Pharmaceutical Sciences Review and Research, 39, 232-236.

Juel, C., (1988). Intracellular $\mathrm{pH}$ recovery and lactate efflux in mouse soleus muscles stimulated in vitro: the involvement of sodium/proton exchange and a lactate carrier. Acta Physiologica Scandinavica, 132, 363-371. https://doi.org/10.1111/j.17481716.1988.tb08340.xKuppast, I., \& Nayak, P., (2006). Wound healing activity of Cordia dichotoma Forst. f. fruits. Niscair Online Periodicals Repository, 5(2), 99-102

Maddu, N. (2019). Chapter 20. Diseases related to types of free radicals. 18pp. In Shalaby, E. (Ed.). Antioxidants. Intech Open. https://doi.org/10.5772/intechopen.82879 https://books.google.iq/books?hl=en \&lr=\&id=vHH8 DwAAQBAJ\&oi=fnd \&pg=PA369\&dq=Diseases + Re lated+to+Types+of+Free+Radicals. $\&$ ots $=$ ON2dCUrT sy\&sig=jGxUw1GbDrxVUEOXUTO0kyIk0hQ\&redi $\mathrm{r} \_$esc $=\mathrm{y} \# \mathrm{v}=$ onepage $\& \mathrm{q}=$ Diseases $\% 20$ Related $\% 20$ to $\% 20$ Types $\% 20$ of $\% 20$ Free $\% 20$ Radicals. \&f=false

Maughan, R., Leiper, J., \& Shirreffs, S., (2013). Haematology. pp. 132-151. In: Eston, R. \& Reilly, T. (Eds.). Kinanthropometry and exercise physiology laboratory manual: Tests, procedures and data. Routledge, 376pp. https://books.google.com.bn/books?id=RA6PAgAAQ BAJ

Okwu, D. E., (2001). Evaluation of the chemical composition of indigenous spices and flavouring agents. Global Journal of Pure and Applied Sciences, 7, 455-459. https://doi.org/10.4314/gjpas.v7i3.16293

Orhan, I. E., (2012). Biotechnological Production of plant Secondary Metabolites. Bentham Science Publishers.https://doi.org/10.2174/978160805114411 20101

Pandey, B., Deshpande, B., Singh, S., \& Chandrakar, V., (2014). Estimation of elemental contents of Cordia myxa and its antimicrobial activity against various pathogenic microorganisms. Indian Journal of Scientific Research, 4, 39-44.

Saki, J., Khademvatan, S., Pazyar, N., Eskandari, A., Tamoradi, A., \& Nazari, P., (2015). In Vitro activity of cordia myxa mucilage extract against Leishmania 


\section{Al-Khafaji et al. /Basrah J. Agric. Sci., 34(2), 267-277, 2021}

major and L. infantum promastigotes. Jundishapur Journal of Microbiology, 8(3), e59827. https://doi.org/10.5812/jjm.19640

Sales-Campos, H., Reis de Souza, P., Crema Peghini, B., Santana da Silva, J., \& Ribeiro Cardoso, C., (2013). An overview of the modulatory effects of oleic acid in health and disease, Mini Reviews in Medicinal Chemistry, 13(2), 201-210. https://www.ingentaconnect.com/content/ben/mrmc/2 013/00000013/00000002/art00003

Sanon, S., Gansane, A., Ouattara, L. P., Traore, A., Ouedraogo, I. N., Tiono, A., Taramelli, D., Basilico, N., \& Sirima, S. B., (2013). In vitro antiplasmodial and cytotoxic properties of some medicinal plants from western Burkina Faso. The African Journal of Laboratory Medicine, $\quad$ 2, a81. https://doi.org/10.4102/ajlm.v2i1.81

Saranya, R., Thirumalai, T., Hemalatha, M., Balaji, R., \& David, E., (2013). Pharmacognosy of Enicostemma littorale: A review. Asian Pacific Journal of Tropical Biomedicine, 3, 79-84. https://doi.org/10.1016/S22211691(13)60028-3

Schmelzer, G., \& Gurib-Fakim, A., (2008). Medicinal plants. 189-191 In Prota. Bakhuys Publishers, Leiden. 790 pp.

https://books.google.iq/books?hlMedicinal+plants\&ot $\mathrm{s}=\mathrm{QwHxqCYcK}-\& \operatorname{sig}$

Souri, E., Amin, G., Farsam, H., \& Barazandeh Tehrani, M., (2008). Screening of antioxidant activity and phenolic content of 24 medicinal plant extracts. Journal of Pharmaceutical Science Daru, 16, 83-87. https://www.sid.ir/en/Journal/ViewPaper.aspx?ID=10 9689
Sparg, S. G., Light, M. E., \& van Staden, J. (2004). Biological activities and distribution of plant saponins. Journal of Ethnopharmacology, 94, 219243. https://doi.org/10.1016/j.jep.2004.05.016

Tanner, J. M., Whitehouse, R. H., Hughes, P. C. R., \& Carter, B. S., (1976). Relative importance of growth hormone and sex steroids for the growth at puberty of trunk length, limb length, and muscle width in growth hormone-deficient children. Journal of Pediatrics, 89, 1000-1008. https://doi.org/10.1016/S0022$3476(76) 80620-8$

Tian, S., Liu, F., Zhang, X., \& Upur, H., (2014). Phytochemical composition and antioxidant capacity of Cordia dichotoma seeds. Pakistan Journal of Pharmaceutical Sciences, 27(5), 1123-1129. https://pubmed.ncbi.nlm.nih.gov/25176355

Valko, M., Leibfritz, D., Moncol, J., Cronin, M. T., Mazur, M., \& Telser, J. (2007). Free radicals and antioxidants in normal physiological functions and human disease. International Journal of Biochemistry \& Cell Biology, 39, 44-84. https://doi.org/10.1016/j.biocel.2006.07.001

Vaughan, R. S., (1991). Potassium in the perioperative period. BJA: British Journal of Anaesthesia, 67, 194200. https://doi.org/10.1093/bja/67.2.194

Yang, Z. H., Lien, P. J., Huang, W. S., Surampalli, R.Y., \& Kao, C.; M. (2017). Development of the risk assessment and management strategies for TPHcontaminated sites using TPH fraction methods. Journal of Hazardous, Toxic, and Radioactive Waste, 21,

D4015003-10. https://doi.org/10.1061/(ASCE)HZ.21535515.0000290 
Al-Khafaji et al. /Basrah J. Agric. Sci., 34(2), 267-277, 2021

\section{البمبر Cordia myxa، هبة الطبيعة: مراجعة بحثية}

ساره عبودي محمد علي الخفاجي1, مهند عبد الحسين حمة السعداوي *2, علي موسى رشيد اليساري33 , مؤيد عبد الحسين حمزة السعداوي

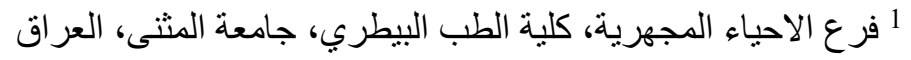

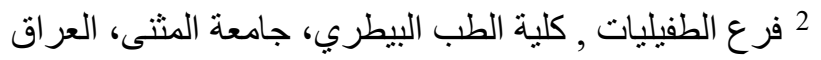

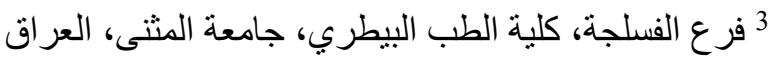

4 طالب ماجستير في الجامعة الجنوبية الوسطى/ الصين وموظف على ملاك مديرية تربية القادسية

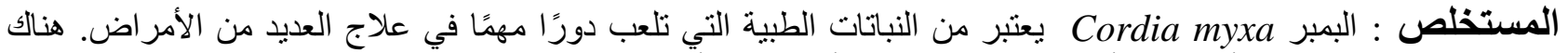

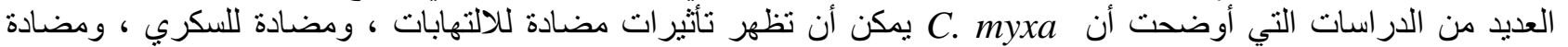
للطفيليات ، ومحفزة للمناعة ومضادة للميكروبات. تم تحضير هذه المر اجعة للتركيز على المركبات النشطة والتأثير ات التئ الدوائية

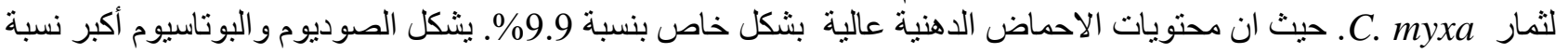

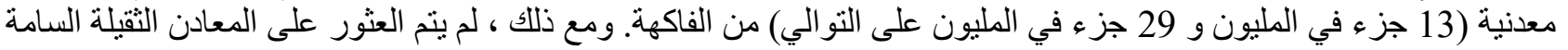

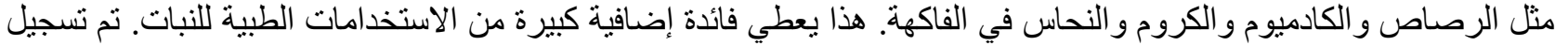

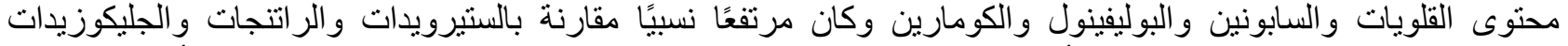

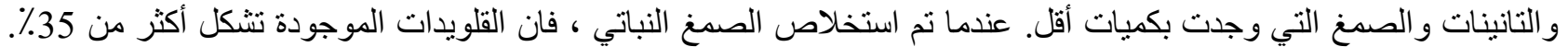

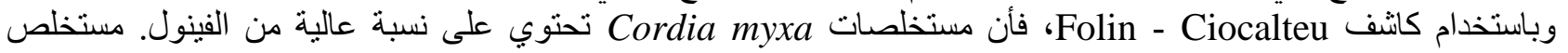

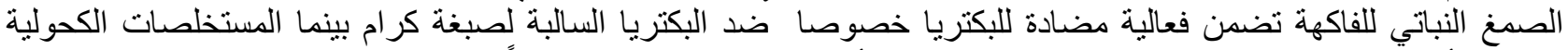

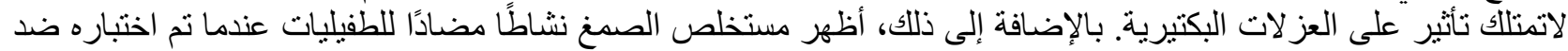

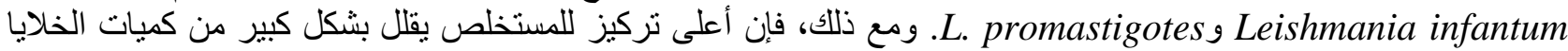
الليمفاوية. علاوة على ذللك ، فإن المستخلصات الإيثانولية لثمار C. myxa تؤدي إلى زيادة عدد الكريات البيض وانئان الخلايا

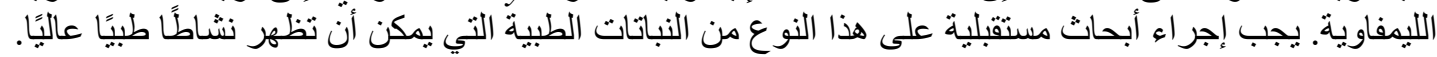

الكلمات المفتاحية: فاكهة البمبر ، المكونات غذائية ، المكونات الكيميائية ، الفعالية المضادة للميكروبات ، الفعالية المضادة للطفيليات ، المحفزات المناعية. 